\title{
Experimental Study of Innovative Indirect Solar Dryers
}

\author{
Tadahmun A. Yassen, Manar S.M. Al-Jethelah*, Hussam S. Dheyab \\ Department of Mechanical Engineering, College of Engineering, Tikrit University, Tikrit 34001, Iraq
}

Corresponding Author Email: m.aljethelah@tu.edu.iq

https://doi.org/10.18280/ijht.390430

Received: 17 August 2020

Accepted: 22 May 2021

\section{Keywords:}

indirect type solar dryer, novel drying chamber, natural convection, flat plate absorber, experimental study, thermal efficiency

\begin{abstract}
The present work experimentally studied two novel solar dryers' designs, novel indirect solar dryer (NISD) and novel mixed indirect solar dryer (NMISD). The purpose behind this work is to compare the thermal performance of the proposed dryers with that of a traditional indirect solar dryer (TISD). The testing method involved building and thermally testing the three dryers. The NISD is a novel drying chamber with three absorbed surfaces. The NMISD consisted of a flat plate solar collector and NISD. The air temperature at the drying chamber entrance increased by $60 \%$ and $68 \%$ for the TISD and NMISD, respectively. In the lower space of the drying chamber, the air temperature was decreased by $35 \%$ while increased by $39 \%$ for the NISD and NMISD, respectively, compared to the TISD. The air temperature in the upper space of the drying chamber increased by $14 \%$ and $49 \%$ for the NISD and NMISD, respectively, compared to the TISD. The temperature variations through the drying chamber were $-26 \%, 33 \%$, and $3 \%$ in the TISD, NISD, and NMISD, respectively. The thermal efficiencies of the NISD and NMISD were $9 \%$ and $55 \%$, respectively, higher than the TISD's.
\end{abstract}

\section{INTRODUCTION}

The solar energy has been widely utilized in different sectors due its economic benefit in long term; besides; it is environmentally-friendly [1-5]. Sun drying is one of the earliest used forms to store and preserve food. The sun drying has more economic benefits compared to conventional and mechanical drying systems [6]. However, there are some drawbacks for sun drying such as bad quality product, contamination, enzymatic reactions, uncontrolled, and timeconsuming. In addition, the dried crops through sun drying suffer from the possibility of being stolen, damaged and infected by animals, and un-uniformly treated [7]. To enhance the drying process and avoid the aforementioned drawbacks, numerous solar dryer types have been proposed and improved $[8,9]$. According to the heat source or the operation mode, solar dryers could be categorized into virous types. Generally, the solar dryers are categorized based on their operation mode into direct, indirect, and mixed dryers. The direct solar dryer concept is that the crops are placed in an air heater covered with a transparent cover, which the solar radiation passes and is absorbed by the crops. The indirect solar dryer implements an air solar heater, as a separate unit, to collect thermal solar energy to heat air. Then the heated air is directed to flow through a crops bed. The mixed solar dryer combines both concepts of direct and indirect solar dryers. The drying air is first heated in a solar heater before it flows through a crops bed that is covered by a transparent cover which ensures direct solar radiation. Solar dryers can be further categorized based on the air flow mode through them as passive and active dryers. The solar dryer is passive when the air flows naturally through them. The solar dryer is active when the air is forced through it. Due to its simplicity and the lack of need to external energy sources other than solar energy, natural convection solar dryers are more convenient and popular in remote and rural areas [10].

The internal temperature of a drying chamber was predicted using Takagi-Sugeno fuzzy (TSF) model by Zoukit et al. [11]. To find the static and dynamic features of the studied dryer for furious meteorological conditions, many experiments were conducted. The solar collector with dimensions of $1 \mathrm{~m}$ width and $2 \mathrm{~m}$ length (collecting area was $2 \mathrm{~m}^{2}$ ). The area of the drying bed was $0.94 \mathrm{~m}^{2}$. They found that the maximum dryer temperature was $57^{\circ} \mathrm{C}$ during Spring season when the solar radiation and ambient temperature were $883.2 \mathrm{~W} / \mathrm{m}^{2}$ and $27.8^{\circ} \mathrm{C}$, respectively. Also, the researchers found, during summer season, that the dryer temperature was $65^{\circ} \mathrm{C}$, when the maximum ambient temperature and solar radiation were $39.6^{\circ} \mathrm{C}$ and $964.1 \mathrm{~W} / \mathrm{m}^{2}$, respectively. Ameri et al. [12] performed a kinetic comparison between direct and indirect solar dryers under natural conditions. Higher temperatures and efficiency were gained for the indirect dryer in comparison with the direct dryer. The results of an indirect solar dryer showed that the maximum drying chamber temperature and ambient temperature were $44^{\circ} \mathrm{C}$ and $24^{\circ} \mathrm{C}$, respectively. It means that the dryer temperature was higher than the ambient temperature by $20^{\circ} \mathrm{C}$. An indirect type solar dryer was designed and developed by Lingayat et al. [13] to dry agricultural products. The components of the studied solar dryer were air collector with V-corrugated plates as absorbers, insulated rectangular drying chamber to, and chimney for heated air. The solar collectors' total area was $2 \mathrm{~m}^{2}$. The dimension of the drying chamber was $1 \mathrm{~m}$ (width) $\times 0.4 \mathrm{~m}$ (depth) $\times 1 \mathrm{~m}$ (height). The results showed that the maximum dryer temperature reached to $78^{\circ} \mathrm{C}$ as the maximum solar radiation reached $1220 \mathrm{~W} / \mathrm{m}^{2}$. It was found that throughout drying the most crucial and effective parameter was the drying air temperature. In addition, it was found that the air velocity 
and humidity had a significant impact to enhance the drying rate. Jain and Tewari [14] investigated the performance of an indirect solar dryer with packed bed PCM which had the capability to store energy after sun shine hours. Implementing the PCM maintained a temperature range, for the drying air, of $40^{\circ} \mathrm{C}-45^{\circ} \mathrm{C}$. As a result, the drying period was extended, and the enhanced performance of the system was confirmed through overnight experiments. The studied dryer had a thermal efficiency of $28.2 \%$. The performance of a crop dryer, i.e. onions, with a reversed absorber based on natural convection condition was studied by Jain [15]. Maximum drying air temperature inside the dryer was $55^{\circ} \mathrm{C}$ at $1: 30 \mathrm{PM}$ when the solar radiation and ambient temperature were 970 $\mathrm{W} / \mathrm{m}^{2}$ and $45^{\circ} \mathrm{C}$, respectively. Madhlopa and Ngwalo [16] studied an indirect passive hybrid dryer, i.e. solar and biomass, with a storage system. The storage system was capable of storing part of the supplied thermal energy to the dryer from the solar energy and the burned biomass. Maiti et al. [17] designed and manufactured an indirect passive solar dryer associated with north-south reflection. It was found that the reflectors enhanced the efficiency of the collector by $18.5 \%$. Othieno et al. [18] studied drying maize in an indirect passive solar dryer consisted of solar air heater and an insulated drying chamber with a chimney. The results showed a reduction in the moisture content from $20 \%$ to $12 \%$ (w.b.) within three days. El-Sebaii [19] studied an indirect passive solar dryer consisted of solar air heater, flat plate type, and a drying chamber. The impact of utilizing a storage material was also studied. Utilizing a storage system reduced the drying time to achieve a moisture content of $18 \%$ by 12 hours. Pangavhane et al. [10] experimentally studied natural convection solar dryer. They found that for the inlet air temperature of $38^{\circ} \mathrm{C}$ the maximum drying air temperature without load condition was $69^{\circ} \mathrm{C}$ at solar irradiance level of $909 \mathrm{~W} / \mathrm{m}^{2}$.

In the present work the development of passive indirect solar dryer has been achieved. In the innovative design, the front, left, and right walls of the drying chamber are constructed to work as solar collectors. The walls were made from aluminum plates and painted in black to absorb the solar radiation. To reduce the heat losses from the walls to the environment, a glaze cover fixed over the walls, and there was a gap of air between the walls and the cover. The proposed design achieved two benefits: heating the drying air and insulating the drying chamber. The comparison between the new design and traditional design of passive indirect solar dryer has been accomplished experimentally.

\section{METHODOLOGY}

This section describes the dryer design, working principle, experimental setup and measurement devices. Three systems were designed and built which were traditional indirect solar dryer (TISD), novel indirect solar dryer (NISD), and novel mixed indirect solar dryer (NMISD). The TISD consisted of a solar collector and insulated drying chamber. The NISD was constructed only from drying chamber working as a solar collector to heat the drying air indirectly. The NMISD was constructed from solar collector and NISD. The experiments

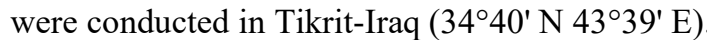

\subsection{Dryer design}

\subsubsection{Solar collector}

A flat plate solar collector, $0.75 \mathrm{~m}^{2}$, facing the south was attached to the front of a drying chamber (Figure 1(a)). Depending on the latitude, the optimum inclination of free convection solar air collector varies from $40^{\circ}$ to $60^{\circ}[3,20,21]$. The studied solar collector was inclined by $40^{\circ}$ from horizon. The collector had a flat plate covered by a hardened glass with a $0.05 \mathrm{~m}$ gap between them. This gap gives the air enough space to flow inside the dryer. The flat plate was coated with dull black color. The solar collector external dimensions were $1 \mathrm{~m} \times 0.85 \mathrm{~m} \times 0.12 \mathrm{~m}$ (length $\times$ width $\times$ depth). The solar collector internal dimensions were $1 \mathrm{~m} \times 0.75 \mathrm{~m} \times 0.07 \mathrm{~m}$ (length $\times$ width $\times$ depth). The solar collector was insulated from its back, left and right sides by a cork with a thickness of 0.05 $\mathrm{m}$. The plate absorbed the incident solar radiation, therefore, the plate temperature raised. As a result, the drying air was heated as it was flowing along the hot plate.

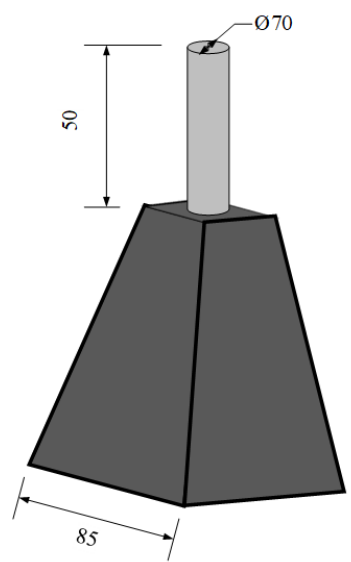

(a)

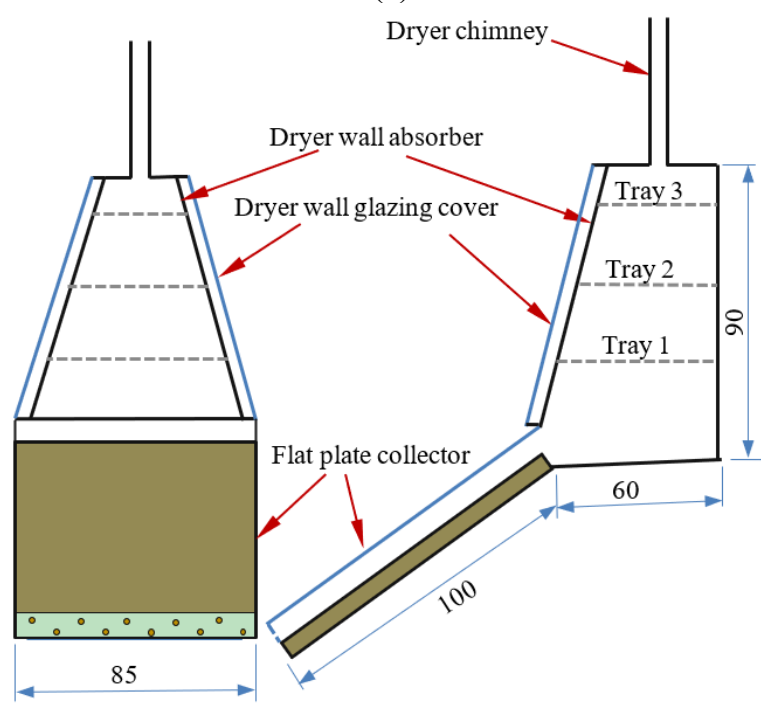

(b)

Figure 1. (a) Drying chamber, (b) Configuration and dimensions of the designed NMISD (all dimensions in $\mathrm{mm}$ )

\subsubsection{Drying chamber}

The drying chamber was made from aluminum angles to reduce weight. The outside dimensions of the dryer were 0.85 $\mathrm{m} \times 0.6 \mathrm{~m} \times 0.9 \mathrm{~m}$ (width $\times$ depth $\times$ height). For the TISD and NMISD, a duct $(0.75 \mathrm{~m} \times 0.07 \mathrm{~m})$ connected the drying chamber with the solar collector directly. There were three drying wire mesh trays in the drying chamber. The total effective drying area was $0.7 \mathrm{~m}^{2}$. To ease loading, unloading, and cleaning, the trays were moveable. The drying chamber walls, i.e., the front, left, and right, were inclined with an angle 
of $75^{\circ}$ from horizon. The dryer door was installed in the back of the dryer, and it was thermally insulated by $20 \mathrm{~mm}$ of cork to avoid heat losses. The dryer door was used to load/unload the products. For the TISD, the chamber walls were insulated with $20 \mathrm{~mm}$ thickness of cork. For the NISD and NMISD, the front, left, and right chamber walls were constructed from aluminum plate gage $1 \mathrm{~mm}$ covered with a glass of $4 \mathrm{~mm}$ thickness. The gap of air between the plate and glass cover was $5 \mathrm{~mm}$. The aluminum plates absorbed the solar radiation that penetrated the glass cover. The absorbed solar radiation then heated the drying air by natural convection. Two galvanized chimneys were fixed on the exhaust of the drying chamber. Each chimney was $0.5 \mathrm{~m}$-length and $0.07 \mathrm{~m}$-diameter. Figure 1 shows the 3-D drawing with design dimensions and the layer of the innovative wall of the NMISD.

\subsection{Working principle}

The working principle of indirect solar dryers is to place moist crops in trays of an opaque drying chamber. The air entering the drying chamber should be hot to dry the crops. In order to heat the entering air, a solar collector is used. Then the hot air passes around the moist crop. The heat supplied by the hot air causes a moisture evaporation from the moist crop to the hot air. The moisture concentration variation of the hot air around the moist crop surface results in dry crop.

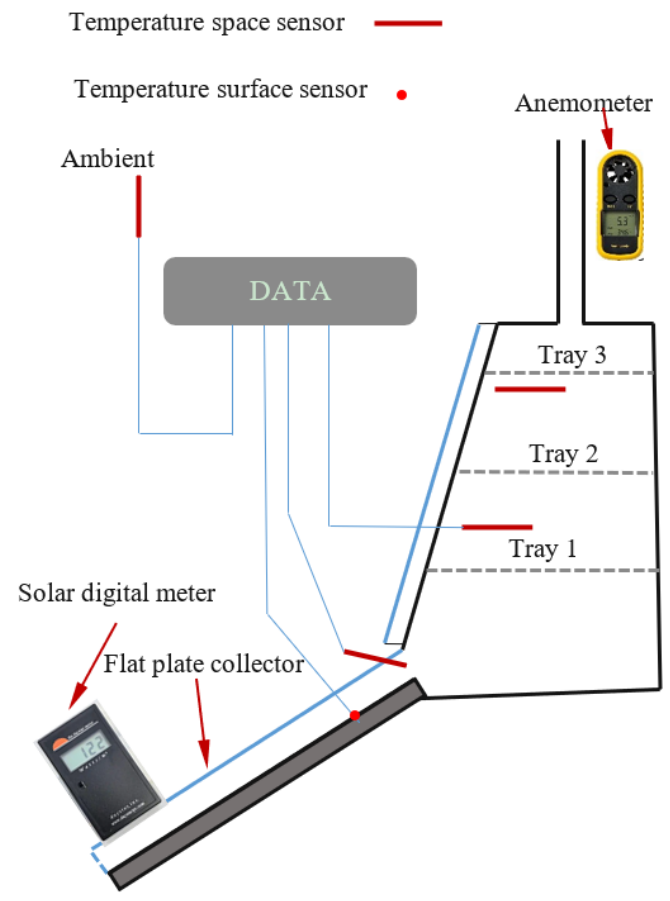

Figure 2. Temperature and solar radiation measurement locations

\subsection{Experimental setup and instrumentations}

The temperature, at various locations as shown in Figure 2, was measured by calibrated K-type thermocouple wires (Chromel-Alumel) with accuracy of $\pm 0.1^{\circ} \mathrm{C}$. The temperature was measured for the flowing air at the collector exit, the drying air at the bottom of the drying chamber, the drying air at the center of the drying chamber, the drying air temperature at the top of the drying chamber, and the ambient. Also, the temperatures of the absorber surface and the left, front, and right surfaces of the drying chamber of the NISD and NMISD were measured, as shown in Figure 2. All the thermocouples were connected to a data logger type Applent AT4808. To measure the velocity of air leaving the collector, a BENETECH GM8 16C anemometer with accuracy of \pm 0.1 $\mathrm{m} / \mathrm{s}$ was used. A solarimeter type daystar.inc DS-05A with accuracy of $\pm 3 \%$ was used to measure the irradiation (I). Figure 3 shows a graphical diagram and photos of the experimental setup.

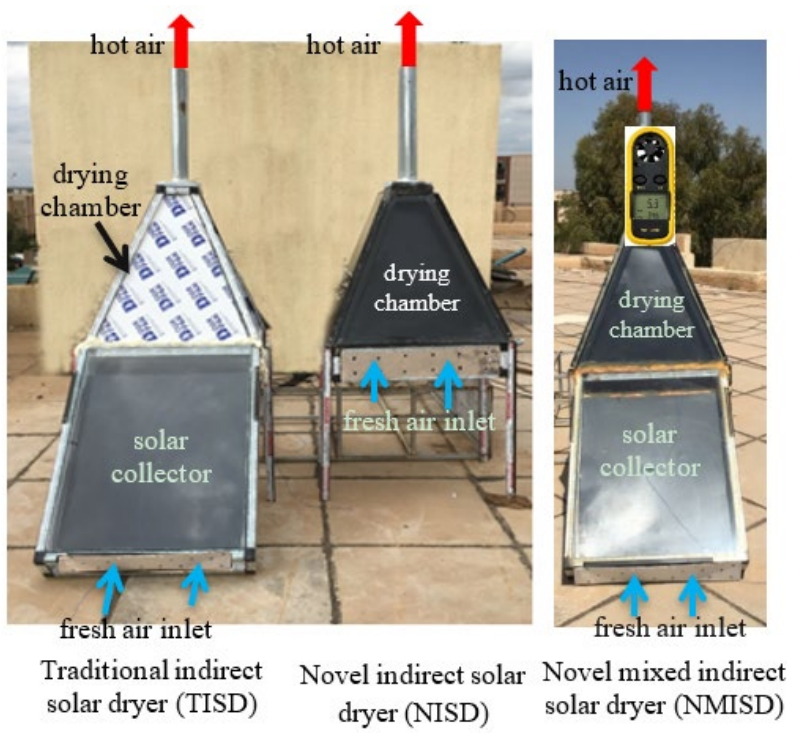

Figure 3. The experimental test rig

\subsection{Thermal energy analysis}

The main goal of any thermal solar system is to convert the solar radiation. To analyze the present solar dryers, an energy balance should be performed as following

$$
E_{s}=E_{u}+E_{l}+E_{s t}
$$

where, $E_{s}$ denotes the solar radiation, $E_{u}$ denotes the useful absorbed thermal energy, $E_{l}$ denotes thermal losses, and $E_{s t}$ denotes the stored energy. Since no thermal energy was stored in the present work, $E_{s t}$ was neglected. Eq. (1) can be re-written as,

$$
E_{u}=E_{s}-E_{l}
$$

The useful absorbed thermal energy can be expressed as

$$
E_{u}=\rho V A_{c} c_{p}\left(T_{\text {out }}-T_{\text {in }}\right)
$$

where, $\rho$ denotes the density of the air, $V$ denotes the air velocity at the chimney exit, and $A_{c}$ denotes the cross-sectional area at the collector/drying chamber entrance, $c_{p}$ denotes the specific heat of air, $T_{\text {out }}$ denotes the drying air outlet temperature, and $T_{\text {in }}$ denotes the drying air inlet temperature.

The thermal efficiency of the system $\left(\eta_{t h}\right)$ can be calculated from [22]

$$
\eta_{t h}=\frac{E_{u}}{\tau \alpha A I}
$$

where, $\tau$ denotes the optical coefficient of transmission of the glazing, $\alpha$ denotes the thermal diffusivity of the absorber, $A$ denotes the absorber area, $I$ denotes the solar radiation. 


\section{RESULTS AND DISCUSSION}

The results in the present work are based on experiments conducted in Tikrit-Iraq $\left(34^{\circ} 40^{\prime} \mathrm{N} 43^{\circ} 39^{\prime} \mathrm{E}\right)$ for four successive days, i.e., March 10 $10^{\text {th }}-13$, 2019 from 9:00 to 15:00. Figure 4 depicts the ambient temperature and the solar radiation recorded during that period. As the recorded parameters were close, the experimental data of March $10^{\text {th }}$ for both the TISD and NISD are presented in this study. The solar radiation during the test hours was ranging from $450 \mathrm{~W} / \mathrm{m}^{2}$ to $1034 \mathrm{~W} / \mathrm{m}^{2}$, and the ambient temperature was ranging from $19^{\circ} \mathrm{C}$ to $22^{\circ} \mathrm{C}$. For the MNISD, the experimental data of March $12^{\text {th }}$ is presented. The solar radiation during the test hours was ranging from $565 \mathrm{~W} / \mathrm{m}^{2}$ to $1036 \mathrm{~W} / \mathrm{m}^{2}$, and the ambient temperature was ranging from $20^{\circ} \mathrm{C}$ to $25^{\circ} \mathrm{C}$.

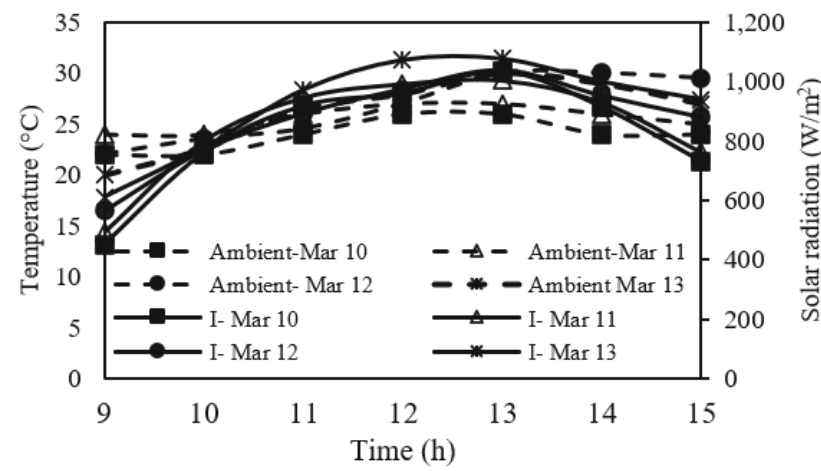

Figure 4. The ambient temperature and the solar radiation from March $10^{\text {th }}$ to 13,2019

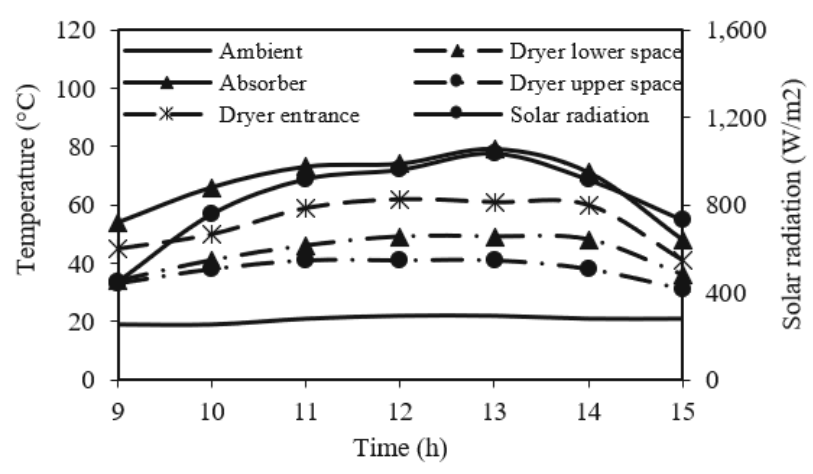

Figure 5. Performance of the traditional indirect solar dryer (TISD)

\subsection{Traditional indirect solar dryer (TISD) analysis}

Figure 5 illustrates the performance of a solar collector and drying chamber for a passive indirect solar dryer (TISD) on March 10 $0^{\text {th }}, 2019$ from 9:00 to 15:00. The maximum reached absorber surface temperature was $79^{\circ} \mathrm{C}$ when the solar radiation reached its maximum value of $1034 \mathrm{~W} / \mathrm{m}^{2}$ at 13:00. The temperature of the air leaving the collector and entering the drying chamber reached its highest value $62^{\circ} \mathrm{C}$ at $12: 00$. After 14:00 PM, the air leaving the collector and entering the drying chamber temperature decreased due to the decrease in the ambient temperature and solar radiation. The air temperature at the lower space of the drying chamber increased due to the increase in the solar radiation. The maximum air temperature at the lower space of the drying chamber was $49^{\circ} \mathrm{C}$ at $12: 00$ and 13:00. The air temperature at the lower space of the drying chamber was higher than the ambient temperature up to $24^{\circ} \mathrm{C}$ at $14: 00$. The air temperature in the upper space of the drying chamber increased due to the increase in the solar radiation. The maximum air temperature in the upper space of the drying chamber was $41^{\circ} \mathrm{C}$ during the period from 11:00 to 13:00. The air temperature in the upper space of the drying chamber was higher than the ambient temperature up to $17^{\circ} \mathrm{C}$ at $11: 00$. It can be noticed a temperature variation through the drying chamber from bottom to top decreased up to $10^{\circ} \mathrm{C}$ at $14: 00$, which creates ununiform environment for drying through the drying chamber.

\subsection{Novel indirect solar dryer (NISD) analysis}

Figure 6 illustrates the performance of the proposed novel indirect solar dryer (NISD) on March 10, 2019 from 9:00 to 15:00. The temperature variations of the front, left, and right dryer internal surfaces were studied. As the cold air entered the drying chamber, it was heated by the drying chamber hot surfaces [23]. During the day, the maximum measured temperatures for the left, front, and right inside dryer surfaces were $74^{\circ} \mathrm{C}$ at $10: 00,91^{\circ} \mathrm{C}$ at $13: 00$, and $63^{\circ} \mathrm{C}$ at $14: 00$, respectively. The left surface temperature reached its maximum value at 10:00 because the maximum incident solar radiation through morning comes from the east. The maximum front surface temperature was at 13:00 because the maximum incident solar radiation within the midday period comes from the south. The right surface reached its highest temperature at 14:00 when the sun moved toward west.

Also Figure 5 shows the drying air temperature in the lower and upper dryer spaces compared to ambient, lower and upper spaces temperatures. The cold drying air entering the drying chamber was heated by the hot drying chamber surfaces only. It can be noticed that the maximum temperature in the lower space reached $33^{\circ} \mathrm{C}$ at $12: 00$. The drying air temperature in the lower space was higher than the ambient temperature up to $8^{\circ} \mathrm{C}$ at 11:00 and 14:00. The maximum recorded drying air temperature in the upper space was $44^{\circ} \mathrm{C}$ from 13:00 to 14:00. The drying air temperature in the upper space was higher than the ambient temperature up to $21^{\circ} \mathrm{C}$ at 10:00. The difference between the upper space and lower space temperatures was up to $14^{\circ} \mathrm{C}$ at $10: 00$.

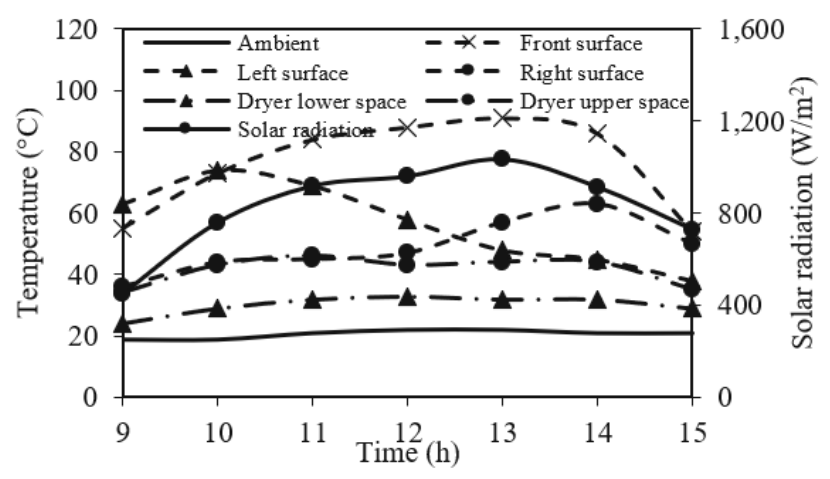

Figure 6. Variation of the environmental condition and the temperatures for the NISD

\subsection{Comparison between the TISD and NISD}

\subsubsection{Temperatures comparison}

Figure 7 illustrates a comparison between a traditional 
indirect solar dryer (TISD) and a novel indirect solar dryer (NISD). For the TISD case, the drying air was heated by the absorber before it entered the drying chamber, as a result, its temperature increased by $17^{\circ} \mathrm{C}$ to $36^{\circ} \mathrm{C}$, i.e. $41 \%$ to $60 \%$, above the ambient temperature. As for the NISD case, the drying air enters directly from the ambient to the drying chamber.

In the lower space of the TISD, the temperature was higher than the ambient from $12^{\circ} \mathrm{C}$ to $24^{\circ} \mathrm{C}$, i.e. $35 \%$ to $50 \%$. As for the NISD, the exposed surfaces of the drying chamber to the sun provided small amount of heat to heat the drying air in the lower space. The drying air temperature in the lower space increased only by $2^{\circ} \mathrm{C}$ to $8^{\circ} \mathrm{C}$, i.e. $8 \%$ to $25 \%$, above the ambient temperature. The drying air temperature in the lower space for the NISD was lower than that for the TISD by $7^{\circ} \mathrm{C}$ to $17^{\circ} \mathrm{C}$, i.e. $-19 \%$ to $-35 \%$. By comparing the achieved increment in the drying air temperatures of the TISD and NISD, utilizing solar collector is recommended to achieve higher temperature in the lower space of the drying chamber.

In the upper space, the drying air in the upper space of the TIDS was higher from $7^{\circ} \mathrm{C}$ to $17^{\circ} \mathrm{C}$, i.e. $23 \%$ to $42 \%$, than the ambient temperature. However, the drying air temperature of the TISD decreased from $1{ }^{\circ} \mathrm{C}$ to $10^{\circ} \mathrm{C}$, i.e. $-3 \%$ to $-26 \%$, compared to that at the lower space. The reduction was caused by the lack of continues heating in the drying chamber, in addition, the drying chamber's components absorbed heat from the hot drying air as it moved through the chamber. As for the NISD, the drying air temperature in the upper space was higher than the ambient temperature from $11^{\circ} \mathrm{C}$ to $21^{\circ} \mathrm{C}$, i.e. $31 \%$ to $49 \%$; and from $6^{\circ} \mathrm{C}$ to $14^{\circ} \mathrm{C}$, i.e. $17 \%$ to $33 \%$, above that in the lower space. This increase was caused by the continues heating for the drying air inside the drying chamber by the chamber surfaces. In the upper space, the drying air temperature of the NISD was higher than that of the TISD from $1^{\circ} \mathrm{C}$ to $6^{\circ} \mathrm{C}$, i.e. $3 \%$ to $14 \%$.

From the aforementioned results, it can be recommended to couple the NISD with a solar collector to obtain higher drying air temperatures in the drying chamber.

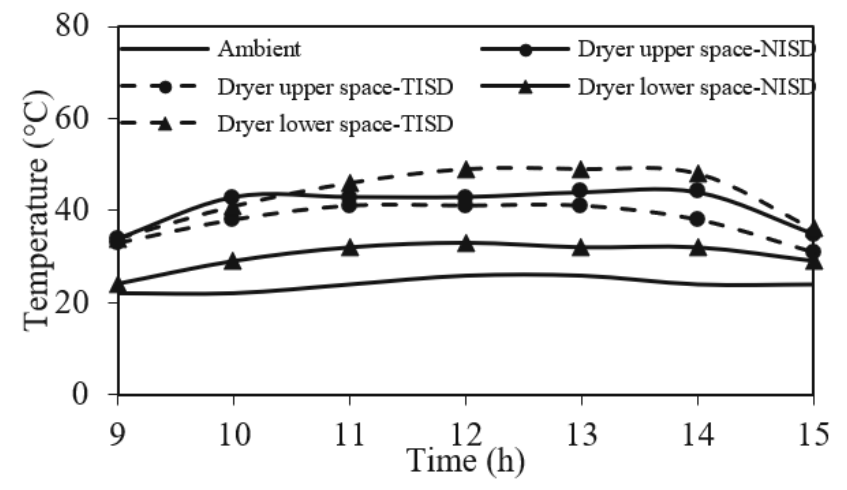

Figure 7. Comparison between the TISD and NISD temperatures

\subsubsection{Thermal efficiency comparison}

Figure 8 depicts the thermal efficiency of both the TISD and NISD. The thermal efficiency of the TISD was between $7 \%$ to $16 \%$, while the thermal efficiency of the NISD was between $13 \%$ to $23 \%$. The thermal efficiency of the NISD was higher than that of the TISD from $4 \%$ to $9 \%$. In the NISD, designing the drying chamber surfaces as absorbers granted receiving continues high solar radiation from east to west. On the contrary, the TISD depends only on the solar collector, which faces south, to heat the drying air. As a result, the drying air gained higher heat in the NISD than that in the TISD, which granted higher thermal efficiency for the NISD.

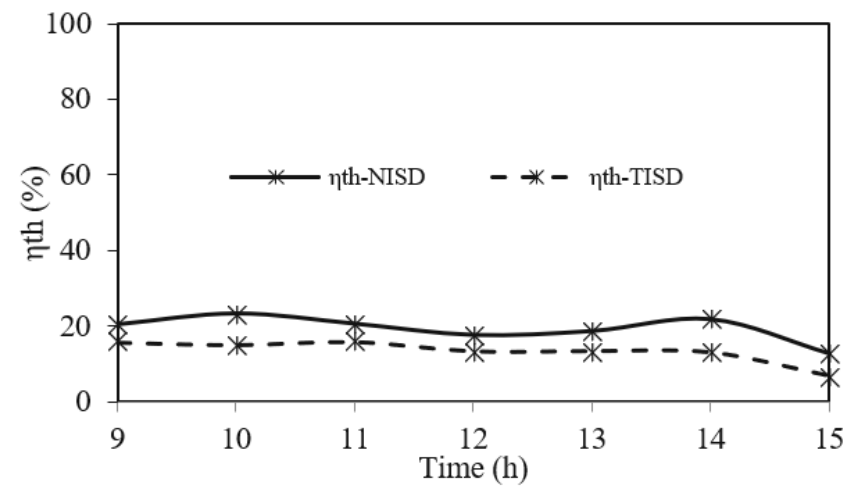

Figure 8. Comparison between the thermal efficiency of the TISD and NISD

\subsection{Novel Mixed Indirect Solar Dryer (NMISD) analysis}

The presented NMISD measurements were conducted on March 13 $3^{\text {th }}$ from 9:00 to 15:00. Figure 9 illustrates the solar radiation and the ambient temperature besides the left, front, and right internal surfaces of the drying chamber. The left, front, and right internal surfaces acted as absorbers. The solar collector absorber surface temperature reached its maximum value, $90^{\circ} \mathrm{C}$, when the solar radiation reached its maximum value, $1036 \mathrm{~W} / \mathrm{m}^{2}$, at 13:00. The maximum measured temperatures of the left, front, and right internal surfaces of the drying chamber were $97^{\circ} \mathrm{C}$ at $10: 00,105^{\circ} \mathrm{C}$ at $13: 00$, and $92^{\circ} \mathrm{C}$ at 15:00, respectively. The left surface temperature reached its maximum temperature at 10:00 because the incident solar radiation during the morning comes from the east. The maximum front surface temperature was at 13:00 because the incident solar radiation within the midday period comes from the south. The right surface maximum temperature was recorded at 15:00 when the incident solar radiation during the afternoon comes from the west

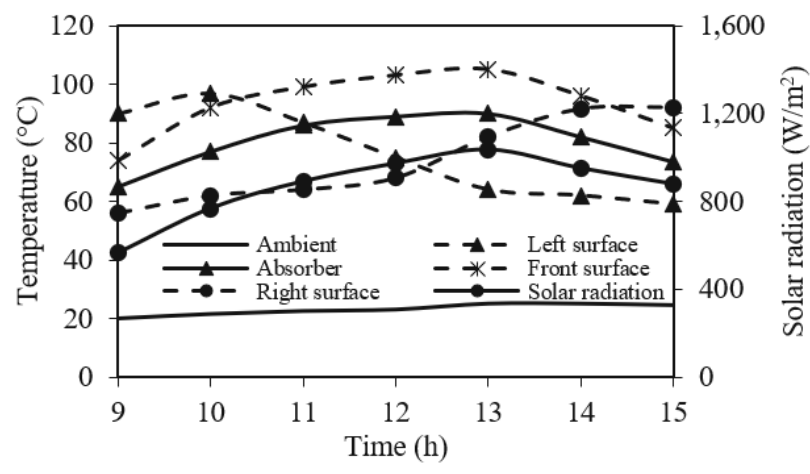

Figure 9. Variation of the environmental condition and the surfaces temperatures of the NMISD

Figure 10 shows the variation of the drying air temperature of the MNISD from the drying chamber entrance to its upper space. The maximum drying air temperature, at the solar collector outlet and drying chamber entrance, was $74^{\circ} \mathrm{C}$ at 13:00 when the solar radiation was at its highest value. The maximum recorded temperatures in the lower and upper spaces of the drying chamber were $67^{\circ} \mathrm{C}$ and $68^{\circ} \mathrm{C}$, 
respectively, at 12:00 and 13:00. The air temperature at the drying chamber entrance was higher than that at the lower space. The reason behind that is the drying air flowing through the solar collector was heated by larger and longer absorbing area than that in the lower space. It can be noticed a temperature difference of $11^{\circ} \mathrm{C}$ at 9:00 between the drying air temperature in the upper and the lower spaces. The hot drying air coming from the solar collector lost part of its heat to the drying chamber components. In addition, the amount of the solar radiation, at the beginning of the test, was not enough to quickly heat up the drying air in the lower space. As the solar radiation increased with time, the drying air temperature was heated faster, and the difference between the upper and lower spaces temperatures decreased to $8^{\circ} \mathrm{C}$ at 10:00. Starting from 11:00 to the end of the test, i.e. 15:00, the drying air temperatures in the upper and lower spaces were very close. The uniformity of the temperature distribution inside the drying chamber revealed that the performance of the NMISD was optimum. The uniformity of the drying air temperature occurred due to the transferred heat from the left, front, and right surfaces of the drying chamber. As well as, the indirectly heat that was provided by the solar collector to the drying chamber. The uniformity of the drying air temperature inside the drying chamber ensured uniform drying.

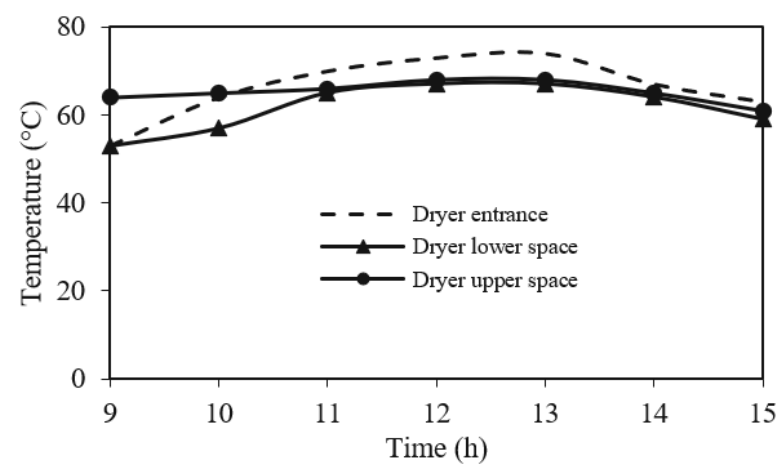

Figure 10. Variation of the drying air temperature for the NMISD

\subsection{Comparison between the TISD and NMISD}

\subsubsection{Temperatures comparison}

Figure 11 depicts a comparison between a traditional indirect solar dryer (TISD) and a novel mixed indirect solar dryer. The drying air at the solar collector outlet and drying chamber entrance of the NMISD was $33^{\circ} \mathrm{C}$ to $50^{\circ} \mathrm{C}$, i.e. $61 \%$ to 68 , higher than the ambient temperature. While for the TISD was $17^{\circ} \mathrm{C}$ to $36^{\circ} \mathrm{C}$, i.e. $41 \%$ to $60 \%$.

In the lower space of the drying chamber, the temperature of the drying air of the NMISD was $33^{\circ} \mathrm{C}$ to $44^{\circ} \mathrm{C}$, i.e. $58 \%$ to $66 \%$, higher than the ambient temperature, compared to $12^{\circ} \mathrm{C}$ to $24^{\circ} \mathrm{C}$, i.e. $35 \%$ to $50 \%$, for the TISD. The drying air temperature in the lower space of the drying chamber of the NMISD was higher than that of the TISD from $16^{\circ} \mathrm{C}$ to $23^{\circ} \mathrm{C}$, i.e. $25 \%$ to $39 \%$.

In the upper space, the drying air temperature in the NMISD was $36.5^{\circ} \mathrm{C}$ to $45^{\circ} \mathrm{C}$, i.e. $60 \%$ to $69 \%$, higher than the ambient temperature. While for the TISD, the drying air was higher by $7^{\circ} \mathrm{C}$ to $17^{\circ} \mathrm{C}$, i.e. $23 \%$ to $42 \%$, than the ambient temperature. The drying air temperature in the upper space was from $1^{\circ} \mathrm{C}$ to $11^{\circ} \mathrm{C}$, i.e. $1 \%$ to $17 \%$, above that in the lower space. It is worthy to point out that the high temperature difference was only for the first two hours of test; for the next five hours, the difference percentage was limited between $1 \%$ and $3 \%$. In the NMISD, the drying air temperature in the upper space was $25^{\circ} \mathrm{C}$ to $31^{\circ} \mathrm{C}$, i.e. $38 \%$ to $49 \%$, above that of the TISD.

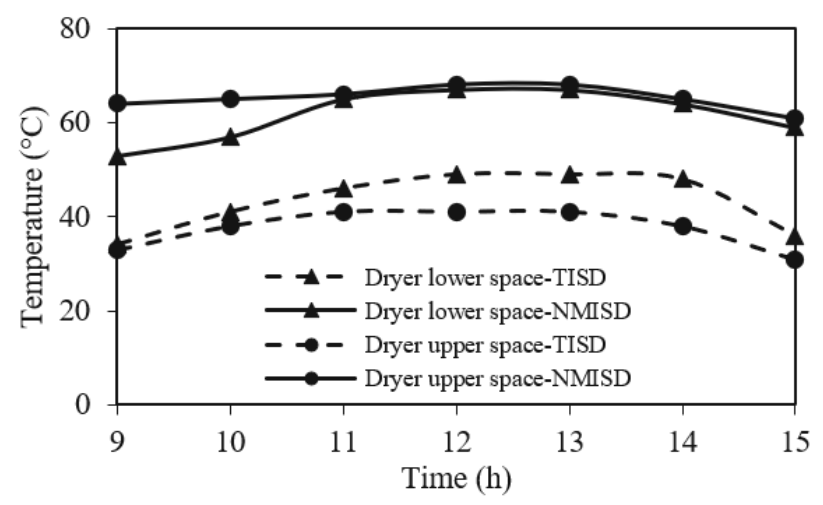

Figure 11. Comparison between the TISD and NMISD temperatures

\subsubsection{Thermal efficiency comparison}

Figure 12 depicts the thermal efficiency of both the TISD and NMISD. The thermal efficiency of the NMISD was between $46 \%$ to $71 \%$; compared to the thermal efficiency of the TISD which was between $7 \%$ to $16 \%$. The thermal efficiency of the NMISD was from $37 \%$ to $55 \%$ higher than the TISD's. These results show that the proposed design (NMISD) has better thermal performance than the traditional indirect solar dryer. Therefore, it can be recommended to use the present innovative design of the indirect solar dryer (NMISD) to gain better thermal performance.

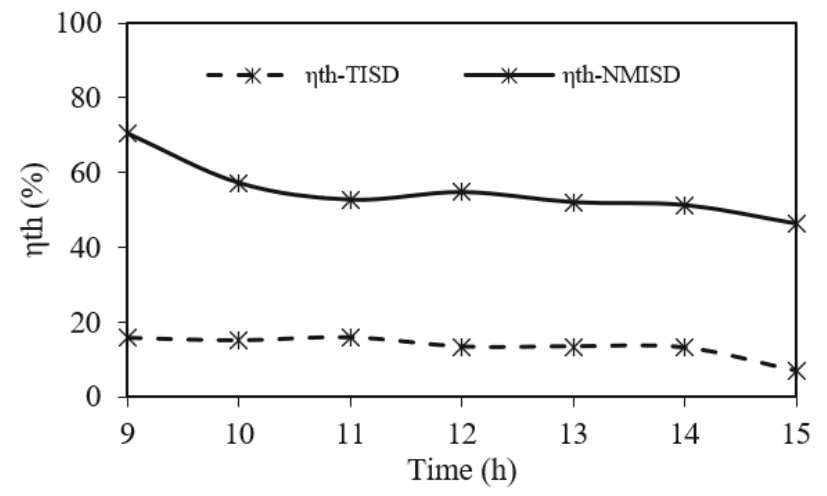

Figure 12. Comparison between the thermal efficiency of the TISD and NMISD

\section{CONCLUSIONS}

Two innovative designs of indirect solar dryer were experimentally investigated in the present study. To perform the investigation, three prototypes of natural convection solar dryers were tested. The investigated dryers were traditional indirect solar dryer (TISD), novel indirect solar dryer (NISD), and novel mixed indirect solar dryer (NMISD). The following conclusions were drawn:

- At the entrance of the drying chamber, compared to the ambient temperature, the drying air temperature was increased up to $60 \%$ in the TISD and up to $68 \%$ in the NMISD. These increments were achieved due to the existence of a solar collector. While for the NISD, the entrance temperature was the same as the ambient 
temperature because its entrance was exposed to ambient.

- In the lower space of the drying chamber, the drying air temperature of the NISD was lower than that for the TISD up to $35 \%$. The lack of heating the drying air before entering the drying chamber caused this reduction in the drying air temperature in the NISD. While, for the NMISD, the drying air temperature was higher than that of the TISD up to $39 \%$. In the NMISD design, both the solar collector and the drying chamber surfaces, which act as absorbers, assured higher temperature in the lower space compared to the TISD.

- In the upper space of the drying chamber, the drying air temperature of the NISD was higher than that of the TISD up to $14 \%$. While, for the NMISD, it was higher up to $49 \%$ than that of the TISD. Both increments were achieved due to the absorbers fixed on the drying chamber surfaces.

- $\quad$ The drying air temperatures difference between the upper and lower spaces in the drying chamber decreased up to $26 \%$ in the TISD, $33 \%$ in the NISD, and $3 \%$ for the NMISD, for most of the test period. As a result, the thermal uniformity through the drying chamber was achieved by using the NMISD.

- The thermal efficiencies of the NISD and the NMISD were $9 \%$ and $55 \%$, respectively, higher than that of the TISD. The improvement in the thermal efficiency of the NMISD was gained due to the existence of both the solar collector and the drying chamber absorbers.

\section{REFERENCES}

[1] Al-Jethelah, M., Tasnim, S.H., Mahmud, S., Dutta, A. (2018). Nano-PCM filled energy storage system for solar-thermal applications. Renewable Energy, 126: 137155. https://doi.org/10.1016/j.renene.2018.02.119

[2] Al-Jethelah, M. (2018). Thermal energy storage for solar energy applications based on regular and composite nano-phase change materials. University of Guelph, Guelph, Canada.

[3] Dheyab, H.S., Al-Jethelah, M.S.M., Yassen, T.A., Ibrahim, T.K. (2019). Experimental study of the optimum air gap of a rectangular solar air heater. Journal of Advanced Research in Fluid Mechanics and Thermal Sciences, 59(2): 318-329.

[4] Boumaraf, L., Khadraoui, R. (2020). Investigation on the performance of a solar hybrid refrigeration system using environmentally friendly fluids. International Journal of Heat and Technology, 38(4): 960-966. https://doi.org/10.18280/ijht.380423

[5] Ni, N. (2020). Thermodynamic features and design of solar-air source composite heating system thermodynamic features and design of solar-air source composite heating system. International Journal of Heat and Technology, 38(4): 967-975.

[6] Puglia, M., Rizzo, A., Morselli, N., Tartarini, P. (2019). Efficiency and economical assessment of a solar powered dryer combined with a biomass gasification system. International Journal of Heat and Technology, 37(3): 705-709. https://doi.org/10.18280/ijht.370306

[7] Bansal, N.K. (1987). Solar crop drying. In Physics and Technology of Solar Energy, 413-445. https://doi.org/10.1007/978-94-009-3939-4_17

[8] Ekechukwu, O.V., Norton, B. (1999). Review of solarenergy drying systems II: An overview of solar drying technology. Energy Conversion and Management, 40(6): 615-655. https://doi.org/10.1016/S0196-8904(98)000934

[9] Benseddik, A., Azzi, A., Khanniche, R., Allaf, A.K. (2018). Simulation study of solar air collector with offset strip fin absorber plate for drying agricultural products in a semi-arid climate. International Journal of Heat and Technology, 36(2): 557-568. https://doi.org/10.18280/ijht.360219

[10] Pangavhane, D.R., Sawhney, R.L., Sarsavadia, P.N. (2002). Design, development and performance testing of a new natural convection solar dryer. Energy, 27(6): 579590. https://doi.org/10.1016/S0360-5442(02)00005-1

[11] Zoukit, A., El Ferouali, H., Salhi, I., Doubabi, S., Abdenouri, N. (2019). Takagi Sugeno fuzzy modeling applied to an indirect solar dryer operated in both natural and forced convection. Renewable Energy, 133: 849-860. https://doi.org/10.1016/j.renene.2018.10.082

[12] Ameri, B., Hanini, S., Benhamou, A., Chibane, D. (2018). Comparative approach to the performance of direct and indirect solar drying of sludge from sewage plants, experimental and theoretical evaluation. Solar Energy, 159:

$722-732$. https://doi.org/10.1016/j.solener.2017.11.032

[13] Lingayat, A., Chandramohan, V.P., Raju, V.R.K. (2017). Design, development and performance of indirect type solar dryer for banana drying. Energy Procedia, 109: 409-416. https://doi.org/10.1016/j.egypro.2017.03.041

[14] Jain, D., Tewari, P. (2015). Performance of indirect through pass natural convective solar crop dryer with phase change thermal energy storage. Renewable Energy, 80:

244-250. https://doi.org/10.1016/j.renene.2015.02.012

[15] Jain, D. (2007). Modeling the performance of the reversed absorber with packed bed thermal storage natural convection solar crop dryer. Journal of Food Engineering, $78(2)$ : 637-647. https://doi.org/10.1016/j.jfoodeng.2005.10.035

[16] Madhlopa, A., Ngwalo, G. (2007). Solar dryer with thermal storage and biomass-backup heater. Solar Energy, 81(4): 449-462. https://doi.org/10.1016/j.solener.2006.08.008

[17] Maiti, S., Patel, P., Vyas, K., Eswaran, K., Ghosh, P.K. (2011). Performance evaluation of a small scale indirect solar dryer with static reflectors during non-summer months in the Saurashtra region of western India. Solar Energy, $\quad 85(11)$ : 2686-2696. https://doi.org/10.1016/j.solener.2011.08.007

[18] Othieno, H., Grainger, W., Twidell, J.W. (1982). Application of small scale solar crop driers to maize drying in Kenya. In Energy for Rural and Island Communities, 377-386. https://doi.org/10.1016/B978-008-027606-9.50047-7

[19] El-Sebaii, A.A., Aboul-Enein, S., Ramadan, M.R.I., ElGohary, H.G. (2002). Experimental investigation of an indirect type natural convection solar dryer. Energy Conversion and Management, 43(16): 2251-2266. https://doi.org/10.1016/S0196-8904(01)00152-2

[20] Mathur, J., Mathur, S. (2006). Summer-performance of inclined roof solar chimney for natural ventilation. Energy and Buildings, 38(10): 1156-1163. https://doi.org/10.1016/j.enbuild.2006.01.006

[21] Yassen, T.A., Al-Kayiem, H.H. (2016). Experimental investigation and evaluation of hybrid solar/thermal 
dryer combined with supplementary recovery dryer. Solar Energy, 134: 284-293. https://doi.org/10.1016/j.solener.2016.05.011

[22] Karoua, H., Moummi, A., Hamidat, A., Moummi, N., Aoues, K., Benchabane, A., Benchatti, A. (2018). Experimental investigation and exergy analysis of an air heater with a solar concentrator used for drying processes. International Journal of Heat and Technology, 36(3): 791-800. https://doi.org/10.18280/ijht.360303

[23] Mahdi, M.S. (2013). Natural convection in a vertical rectangular enclosure. Kirkuk University Journal for $\begin{array}{lll}\text { Scientific } & \text { Studies, } & \text { 8(4): }\end{array}$ https://doi.org/10.32894/kujss.2013.87984

\section{NOMENCLATURE}

A surface area of the absorber duct $\left(\mathrm{m}^{2}\right)$ cross-sectional area at the collector/drying chamber $A_{c} \quad$ entrance $\left(\mathrm{m}^{2}\right)$

$c_{p} \quad$ specific heat of air $\left(\mathrm{J} \mathrm{kg}^{-1} \mathrm{~K}^{-1}\right)$

$E \quad$ thermal energy (W)

$I \quad$ solar radiation $\left(\mathrm{W} \mathrm{m}^{-1}\right)$

$T$ temperature $\left({ }^{\circ} \mathrm{C}\right)$

$V \quad$ air velocity $(\mathrm{m} / \mathrm{s})$

\section{Greek symbols}

$\alpha \quad$ thermal diffusivity

$\rho \quad$ air density $\left(\mathrm{kg} / \mathrm{m}^{3}\right)$

$\tau \quad$ optical coefficient of transmission of the glazing

$\eta_{t h} \quad$ thermal efficiency

\section{Subscripts}

in inlet

out outlet 